DOI 10.18551/rjoas.2019-05.18

\title{
THE SUSTAINABILITY STATUS ANALYSIS OF PARI KEMBANG (DASYATIS KUHLII) RELATED TO CANTRANG FISHING RESULTS WITH RAPFISH METHOD IN LAMONGAN OF EAST JAVA, INDONESIA
}

\author{
Parmanto \\ Master's Program in Marine Sciences, Faculty of Mathematics and Natural Sciences, \\ University of Indonesia, Indonesia \\ E-mail: farant165@gmail.com
}

\begin{abstract}
For the last decade, rays fishery in Lamongan suffers a decline in both amount and size. Lamongan is one of districts (Kabupaten) in East Java, Indonesia, serving as East Java's largest producer of Pari Kembang (blue spotted rays), with Brondong National Fishery Ports (PPN Brondong) as its central. This research aims to identify the sustainability of Pari Kembang fish caught by Cantrang (Danish trawl) fishing method. This research was carried out for 3 months from August 2018 to October 2018. The research method used in this research to determine the sustainability status of Rays fishery was Rapid Appraisal Fisheries (RAPFISH) method. The respective results of all dimensions researched: ecological index is 51.87, economic index is 44.71, social index is 44.67, technological index is 41.86 and ethical index is 45.06 . The multidimensional sustainability level of ray fish conservation in Lamongan is fairly low with 47.57 index.
\end{abstract}

\section{KEY WORDS}

Blue spotted rays, sustainability, Danish trawl, RAPFISH, Lamongan.

Rays is one of sustainable fisheries in Indonesia. Rays fishery in Indonesia has various types of ray fish and the largest fishery product is Pari Kembang (Blue spotted rays). This fish live in tropical and subtropical seas. In Indonesia, Pari Kembang is mainly found in Java Sea and southern part of Java. Indonesia is one of largest ray fish producer in the world (Utami, et al., 2014). Brondong National Fishery Port (PPN Brondong) is a fishery port which operates regionally. Deprived fishermen are forced to exploited certain fishes regardless overfishing condition and environmental damage. Fauzi (2005) states that poverty suffered by fishermen in the coast may indirectly disturb the food chain in the seas, resulting in the decline of fishery products. Deprived fishermen are both the victim and the one who damage the environment. Therefore, the improvement of fishermen income can preserve the sustainability of fishery products.

In East Java, there are two national ports. One port is in the north part of East Java and the other one is in the south. PPN Brondong in Lamongan is the one at the north. While PPN Prigi in Trenggalek is the one at the south. Lamongan is the greatest producer of ray fish. Rays fishery production in Lamongan, 2013-2017 period has reached 4,787 tons (PPN Brondong 2017) Rays fishery production in Trenggalek, 2013-2017 period has reached 19.629 tons (PPN Prigi 2017). In the last decade, there is a significant decline in the production of rays' fishery.

This decline can be caused of several factors. The cause are (1) overfishing, (2) the lower quality of the sea waters chemically, physically and biologically. The decrease of fishery is frequently happened especially in the coast. Adam et al., 2013 states that fishery results are relied on the sea's fishery resources in the fisheries cultivation area (WPP). The other possible reason is overfishing in a certain amount of time, overfishing occurs when there is a significant size decrease of the caught fish (Dudley\& Simpfendorfer, 2006 in Fahmi, 2008).

Pari Kembang which has been caught is varied in size. All the fish are for sell. There is no selective fishing to Pari Kembang fish, affecting its sustainability significantly. If we let the condition as it is right now, Pari Kembang will surely go extinct. There is also no further 
consideration that their next generation may not be able to see Pari Kembang fish. They believe that we should use available resources as much as we can for our current needs.

The management of sustainable fishery is not only to preserve the fish (as resources) for economic purposes but also it is for the fishermen themselves (sustainable community) that is supported by the existence of institution managing the quality of rules, policy and organization to preserve sustainable biology, economy and community (Adrianto, 2004) The new paradigm of sustainable fishery stated by Charles (2001) explores various aspects, namely: First is ecological sustainability, such as preserving fish stock as well as increasing capacity and the quality of ecosystem. The second is socio-economical sustainability, by taking attention to the sustainable economic condition of the business actors.

Manage or improve the economic level of the community is the next priority. The third is the sustainability of community, including the prosperity of the community. Lastly, the sustainability of institution which manage healthy financial and administration aspects as the third requirement of sustainable development.

\section{LITERATURE REVIEW}

According to the evolution theory, ray fish are derived from shark family that adapt as bottom dweller. The pressure in the bottom of the sea had shaped shark into ray fish (flat form) (Manik, 2003) Based on Nelson, 1976 in Manik, 2003, ray fish are classified into:

- Kingdom: Animalia;

- Filum: Chordata;

- Subfilum: Chondrichtyes;

- Subclass: Elasmobranchii;

- Familiy: Dasyatidae;

- Species: Dasyatis kuhlii.

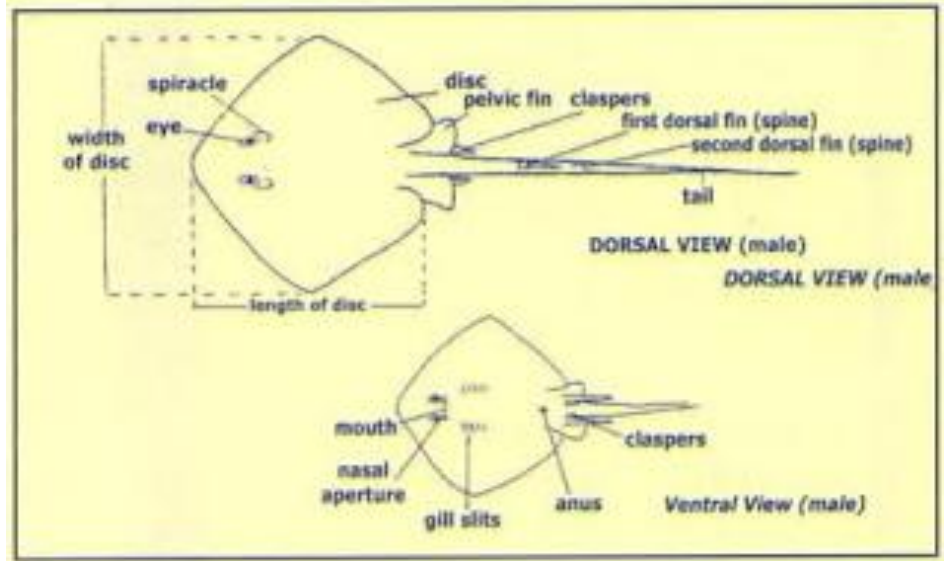

Figure 1 - Rays' morphological shape (Source: http://mukhtar-api.blogspot.com)

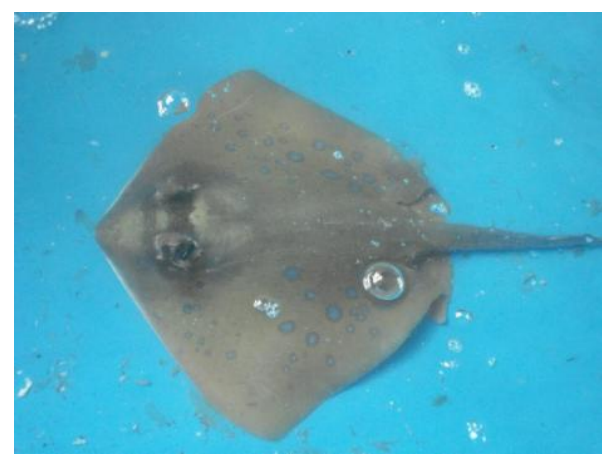

Figure 2 - Pari Kembang Fish / Blue spotted rays (Source: http://fauna-of-indonesia.blogspot.com/2013) 
The suitable environments for ray fish to live are seas with narrow coast, mud and sand substrate, reef, lagoon, bay or estuary. Rays can live in the deep sea up to 2,000 m below the surface. Rays breed in ovoviviparous manner (laying eggs and giving birth) that produces 4-6 young ray fish (Hart, 1973).

The development of sustainable fishery has 3 main aspects namely ecology, economy and social. The development of fishery economically is considered sustainable, if the fishery sector is able to produce sustainable fish products (on continuing basis), giving prosperity to business actors as well as tax and foreign exchange for the country. The development of fishery ecologically is considered sustainable, if we can preserve the stability of the fish stock availability, keep the resources from overfishing, and manage the waste accordingly. The development of fishery socially is considered sustainable, if the basic needs (food, clothing, health and education) of the fishermen are fulfilled, income and job field are distributed equally, gender equality and managed social conflict.

\section{METHODS OF RESEARCH}

This research was conducted in PPN Brondong, Lamongan, East Java. Its coordinates is $06^{0} 52^{\prime} 11.64^{\prime \prime}$ to $06^{0} 52^{\prime} 09.29^{\prime \prime}$ latitude and $112^{0} 17^{\prime} 15.06^{\prime \prime}$ to $112^{0} 17^{\prime} 56.17^{\prime \prime}$ longitude. This research was conducted for 3 months, from August - October 2018.

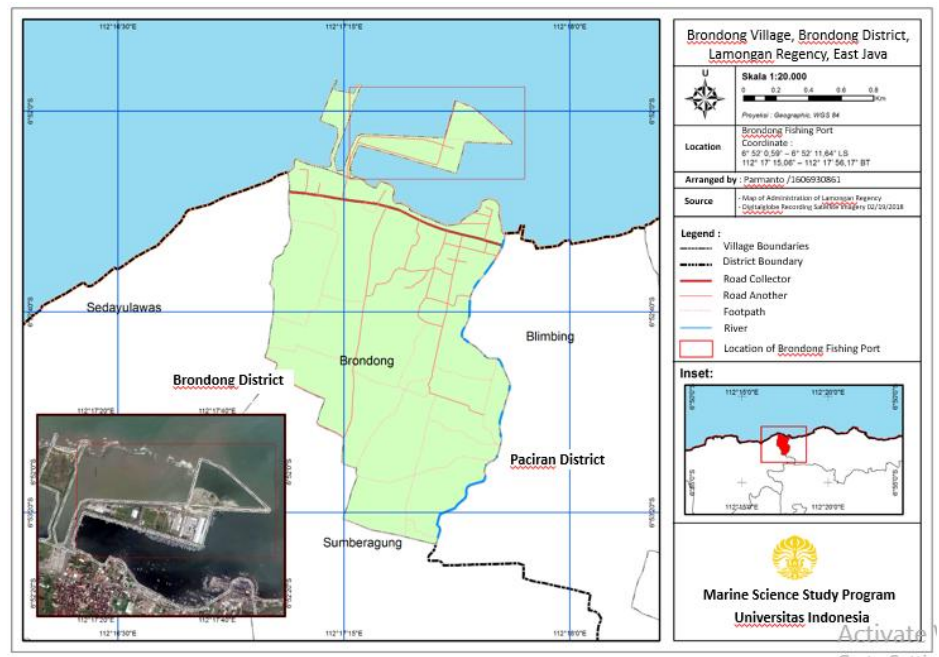

Figure 3 - Research Location

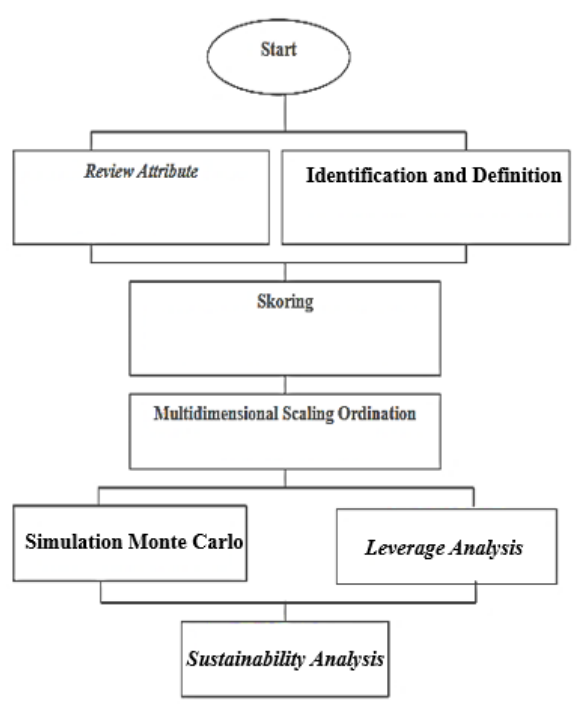

Figure 4 - The implementation of RAPFISH (Source: Alder et al. 2000) 
Sustainability aspects include ecological, social, economic, ethical and technological aspects with RAPFISH questionnaire tool. Questioner was done by direct interview to 26 respondent including, PPN Brondong, Lamongan Marine Affairs and Fisheries Department, PSDKP Supervisory Working Unit, ship owner, ship captain, fishermen community's leader, and academics. A low stress value indicates a good result which is more relevant to reality, whereas a high $S$ value indicates the opposite. In RAPFISH method, a good stress value is ranging between $0.25(\mathrm{~S}<0.25)$.

Table 1 - The sustainability criteria of fishery development

\begin{tabular}{|c|c|}
\hline Index/Criteria & Category \\
\hline $0-25$ & Unsustainable \\
\hline$>25-50$ & Less Sustainable \\
\hline$>50-75$ & Fairly Sustainable \\
\hline$>75-100$ & Sustainable \\
\hline
\end{tabular}

Source: Susilo, 2003.

\section{RESULTS AND DISCUSSION}

Rays Fishery in Lamongan is carried out by local fishermen and only 1 ship that come from Surabaya. Some of them do the fishing in one day (one day fishing) and some of them may fish for maximum 21 days. In Fridays, local fishermen do not go to sea to fish. Ray fish fishing by local fishermen in Lamongan use Cantrang (Danish trawl) or dogol.

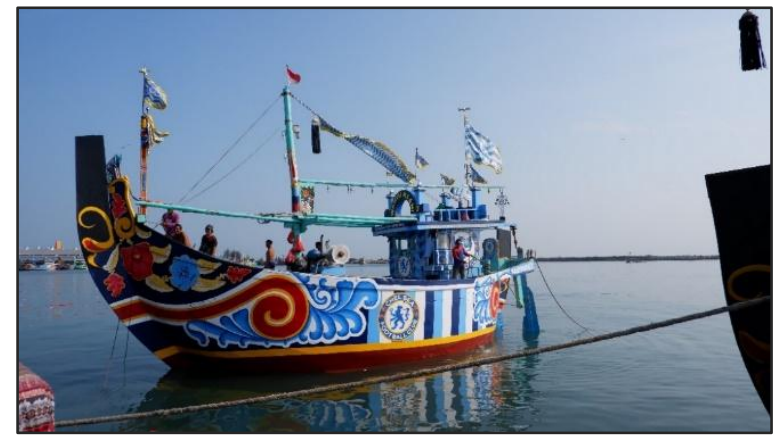

Figure 5 - Ship with Cantrang

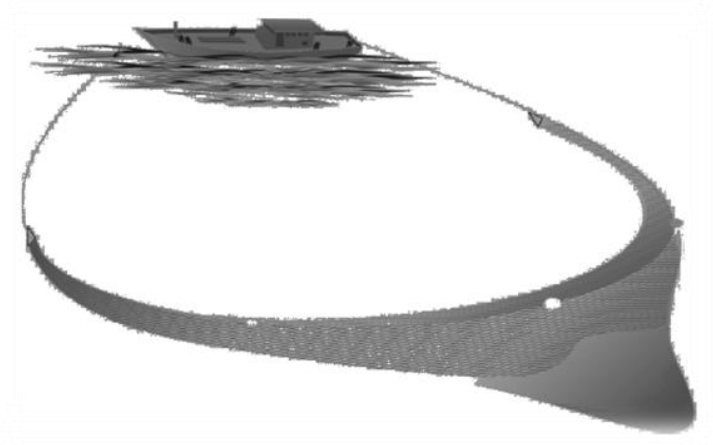

Figure 6 - Cantrang fishing tool

The main function of Cantrang is catching demersal fish. It means that Cantrang is designed to catch bottom dweller (demersal) and shrimp and Petek fish, Biji nangka fish, gulamah fish, kerapu fish, sebelah fish, stingray, cucut fish, octopus, bloso fish and various kind of shrimps (Subani and Barus 1989). The main parts of this tool are pouch, body, wings or feet, headline rope, warp wires, floats and weights. Cantrang nets are made of polyethylene. 
The size of net in the pouch is 1 inch. The body is made of polyethylene and the size of the net is 1.5 inch minimum. The wing is made of polyethylene and the size of the net is 5 inch minimum. Weights are made from tin or other material. Warp wires are made of polyethylene. Warp wires are 1.000 meters long (left and right, $500 \mathrm{~m}$ respectively) yielding a wide catching range. The size of Cantrang and warp wires used are determined by the ship's size. Most ships with Cantrang in Lamongan are 13 meters long, 6.5 meters wide and 1.7 meters tall with 21-28 GT tonnage.

Fishing tool in Lamongan are varied. Some of them are dogol/cantrang, payang, rawai, gilnet, purse seine, and trammelnet. Cantrang is the most common fishing tool in Lamongan. Cantrang is actually illegal in Indonesia; it is prohibited by Ministry of Marine Affairs and Fisheries. The rule is stated in Ministerial Regulation of Marine Affairs and Fisheries Number 2/Permen-KP/2015 concerning The Prohibition of Trawls and Seine Nets Fishing Tools in Republic of Indonesia's Fisheries Cultivation Area.

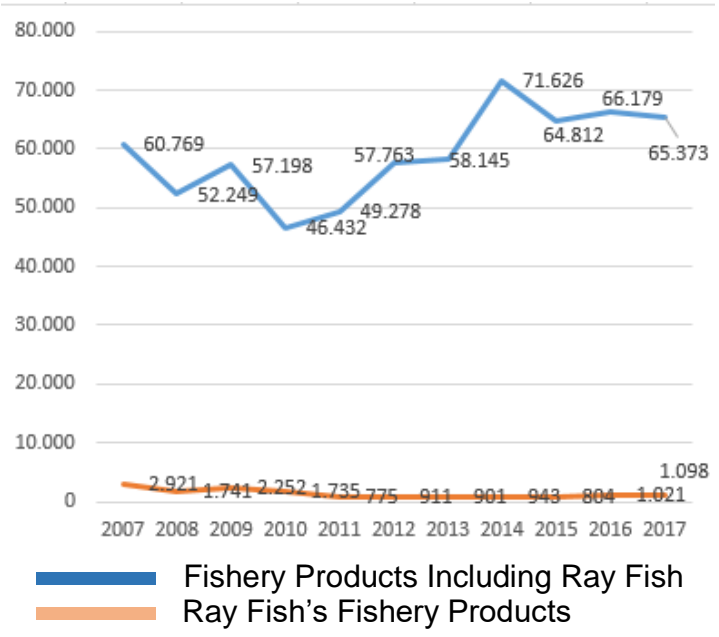

Figure 7 - Fishery production in Lamongan 2007 - 2017, landed at PPN Brondong (2017)

Figure 7 depicts fishery production (blue line) in Lamongan and rays fishery (red line). It also records the highest fishery production, which is in 2014 that reaches 71,626 tons, while the lowest production is in 2010 that only reaches 46,432 tons. In addition, the highest rays fishery is in 2007 that reaches 2,921 tons, while the lowest production is in 2011 that only reaches 775 tons. The fluctuation of the average fishery production is caused by climate changes that directly affect fishery activities.

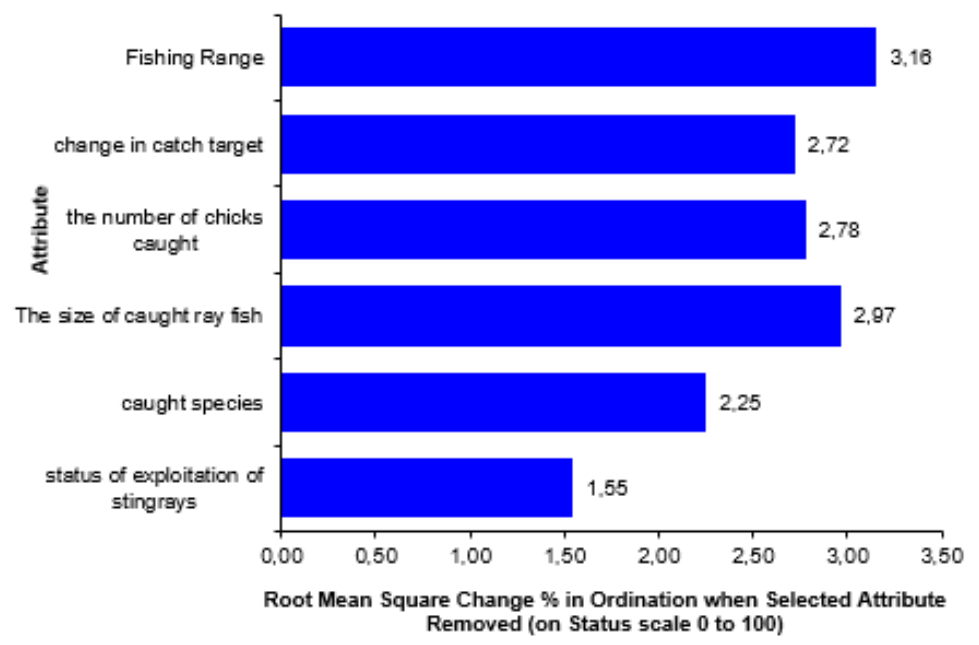

Figure 8 - Attribute analysis results of ecological dimension 
To determine the sustainability of rays fishery in Lamongan, we conducted an analysis using RAPFISH method with 5 (five) dimensions namely ecology, economy, technology, social status, and ethic. By analyzing all the five dimensions, we calculated sustainability index of rays' fishery in Lamongan.

Figure 8 depicts the main factors of ecological dimension: fishing range; the size of caught ray fish.

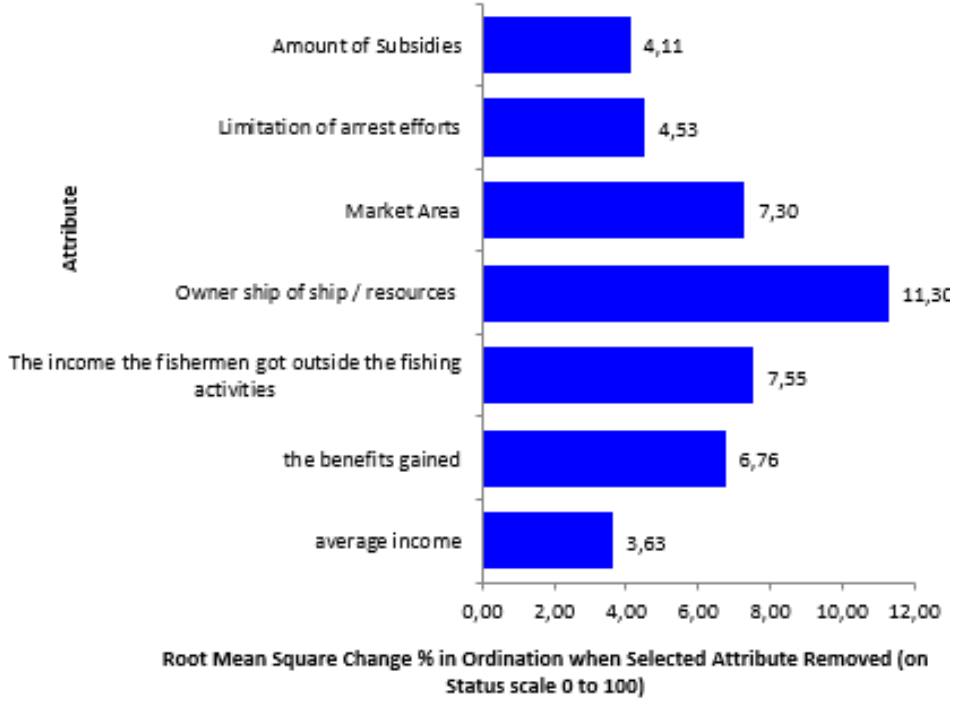

Figure 9 - Attribute analysis results of economic dimension

Figure 9 depicts the main factors of economic dimension: ownership of ship / resources; the income the fishermen got outside the fishing activities; market area.

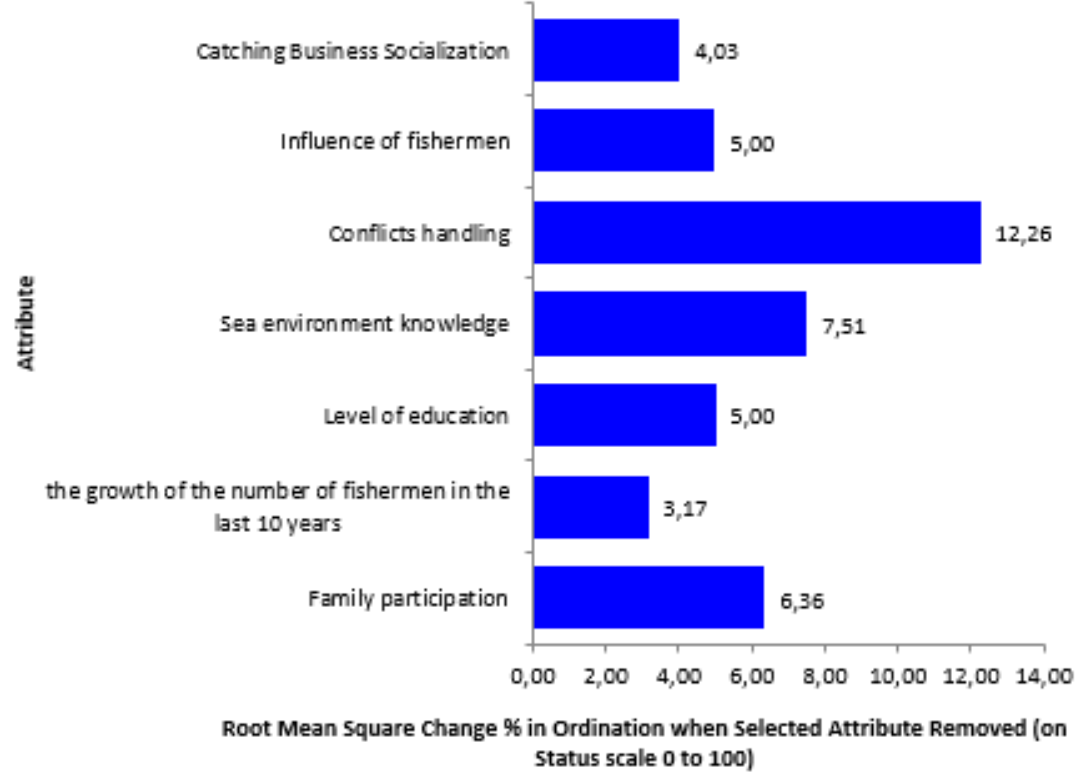

Figure 10 - Attribute analysis results of social dimension

Figure 10 depicts the main factors of social dimension: conflicts handling; sea environment knowledge; family participation. 


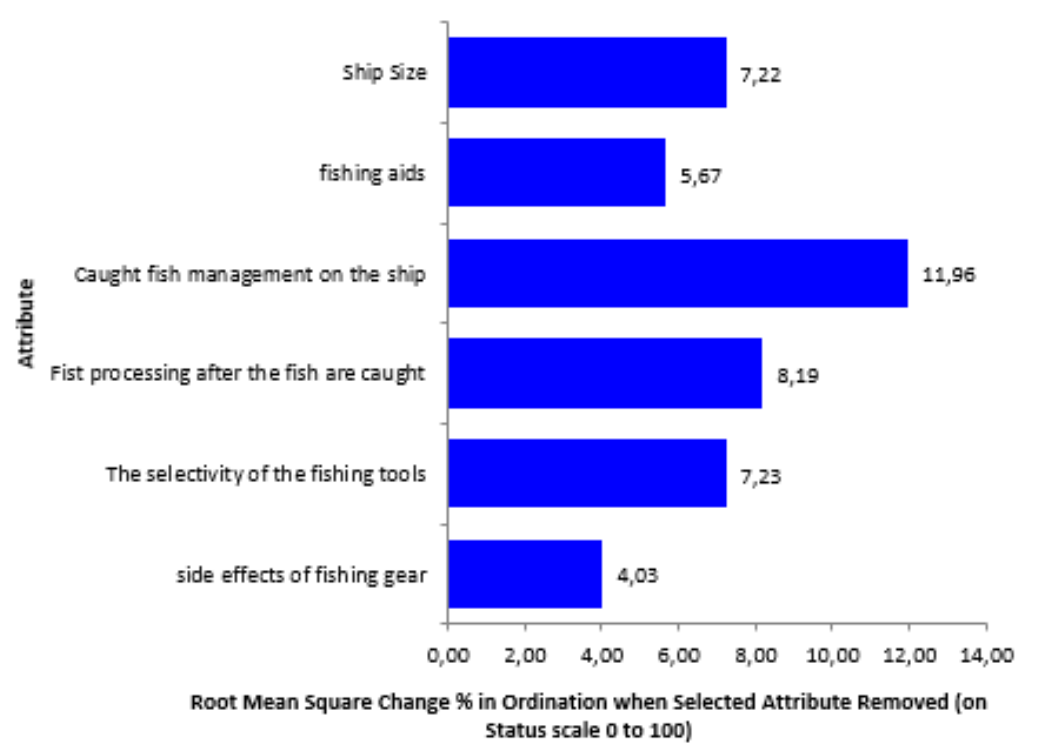

Figure 11 - Attribute analysis results of technological dimension

Figure 11 depicts the main factors of technological dimension: caught fish management on the ship; fist processing after the fish are caught; the selectivity of the fishing tools.

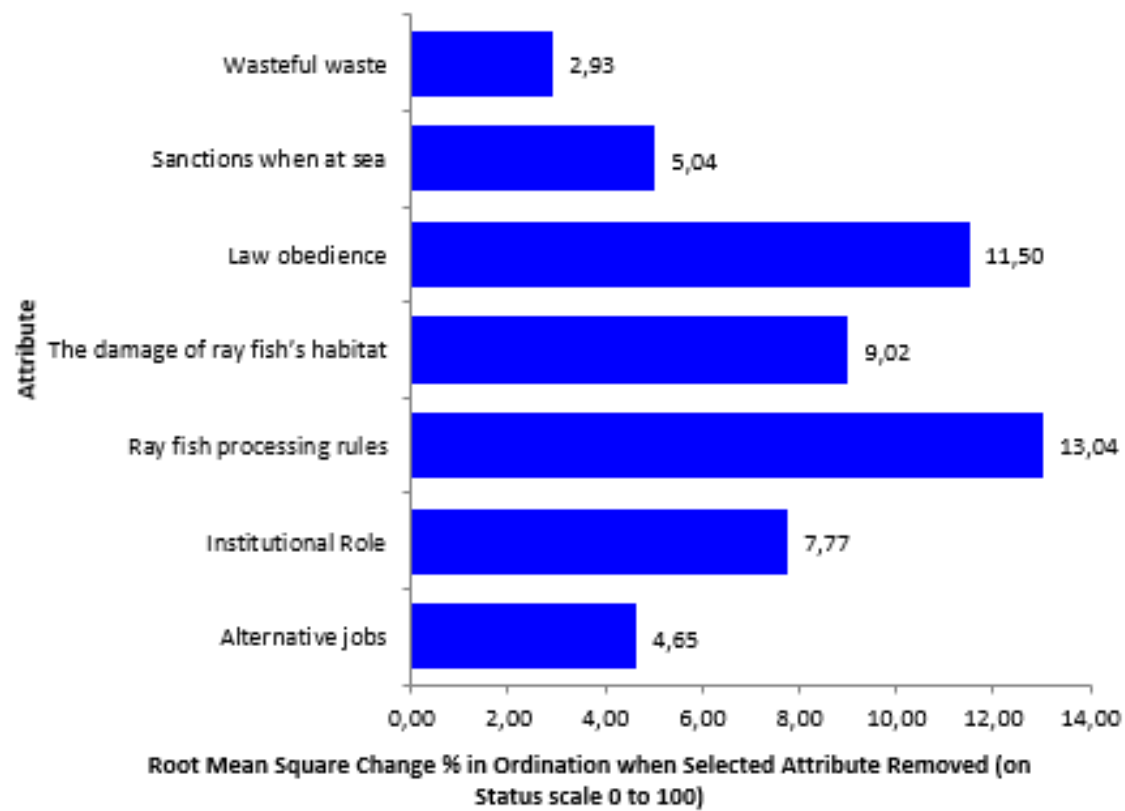

Figure 12 - Attribute analysis results of ethical dimension

Figure 12 depicts the main factors of ethical dimension: ray fish processing rules; law obedience; the damage of ray fish's habitat.

Table 2 - Analysis results of RAPFISH and Monte Carlo

\begin{tabular}{ccccc}
\hline No & Dimension & RAPFISH Analysis & Monte Carlo & The differences \\
\hline 1 & Ecology & 51.87 & 51.25 & 0.62 \\
\hline 2 & Economy & 44.71 & 44.61 & 0.10 \\
\hline 3 & Social & 44.67 & 43.72 & 0.95 \\
\hline 4 & Technology & 41.86 & 39.99 & 1.87 \\
\hline 5 & Ethic & 45.06 & 44.80 & 0.26 \\
\hline
\end{tabular}


Monte Carlo's analysis related to condition and status of ray fish sustainability in Lamongan with $90 \%$ confident level shows similar result with RAPFISH analysis. It can be concluded that analysis mistakes can be minimized in scoring each attribute. There is also small variant in scoring caused by the difference of opinions. The difference of index values between RAPFISH analysis result and Monte Carlo are depicted in Table 2.

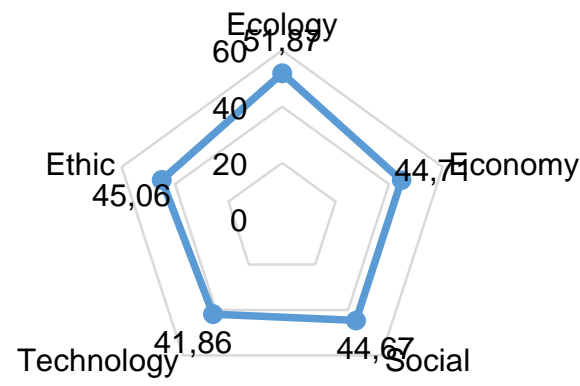

Figure 13 - Ray fish's sustainability status diagram

The next step is pairwise comparison test. According to Budiharsono (2005), sustainability status of fishery cannot be determined by identifying the average value of the five dimensions used as indicator, but by conducting pairwise comparison. The use of pairwise comparison matrix (coupled matrix) to yield relative as well as alternative weight between criteria. One criteria is compared to the other concerning its relation to the research objective (Saaty, 1986).

Pairwise comparison calculation is done by weighing the selected weight by experts who excel in the cultivation of fisheries. Pairwise comparison is had to done since each dimension has different weight. Acquired calculation result, we have weighed score as depicted in Table 3.

Table 3 - Index values of multidimensional sustainability

\begin{tabular}{ccccc}
\hline No & Dimension & Weighed weight & Index Values & Weighted Index Values \\
\hline 1 & Ecology & 0.440 & 51.87 & 22.82 \\
\hline 2 & Economy & 0.283 & 44.71 & 12.65 \\
\hline 3 & Social & 0.112 & 44.67 & 5.00 \\
\hline 4 & Technology & 0.121 & 41.86 & 5.07 \\
\hline 5 & Ethic & 0.045 & 45.06 & 2.03 \\
\hline & Sum & & 47.57 \\
\hline
\end{tabular}

Table 4 - The analysis result of stress value RAPFISH and coefficient of determination

\begin{tabular}{cccccc}
\hline No & Dimension & Index Values & Category & Stress & $\mathrm{R}^{2}$ \\
\hline 1 & Ecology & 51.87 & Fairly Sustainable & 0.19 & 0.90 \\
\hline 2 & Economy & 44.71 & Less Sustainable & 0.19 & 0.90 \\
\hline 3 & Social & 44.67 & Less Sustainable & 0.19 & 0.90 \\
\hline 4 & Technology & 41.86 & Less Sustainable & 0.19 & 0.90 \\
\hline 5 & Ethic & 45.06 & Less Sustainable & 0.19 & 0.90 \\
\hline
\end{tabular}

We can see that weighed result from the experts who excel in the cultivation of fisheries yield 47.57 weighted index values which is $>25-50$ range. This means that rays fishery with cantrang in Lamongan is classified as less sustainable resources. RAPFISH analysis result shows that all of the attributes assessed to rays sustainability status are fairly accurate. This can be identified by the stress value which is between 0.19-0.20 with the value of coefficient of determination (R2) 0.90 for all assessed dimension. The value shows that the attributes used to determine sustainability status of each dimension are fairly relevant, since the stress value is smaller than $25 \%$ as shown in the table. 


\section{CONCLUSION}

Multidimensional sustainability status of rays' fishery in Lamongan is classified as less sustainable resources. Two main factors of each dimension are as follows: ecological dimension (fishing range, the size of caught ray fish), economic dimension (ship ownership, other income outside fishing), technological dimension (fish processing on the ship, selectivity of the fishing tools), ethical dimension (ray fish cultivation rules, law obedience).

\section{REFERENCES}

1. Adam, L. \& Surya, T.A. 2013. Kebijakan pengembangan perikanan berkelanjutan di Indonesia. P3DI Bidang Ekonomi dan Kebijakan Publik. General Secretary of DPR RI.

2. Adrianto L. 2004. Menggagas visi ekonomi-ekologi (Ecological Economics) dalam perspektif paradigma baru pembangunan ekonomi dan lingkungan menuju terwujudnya indonesia berkelanjutan (Sustainable Indonesia). PKSPL-IPB. Bogor.

3. Charles, Anthony T. 2001. Sustainable fishery system. Blackwell Scientific Publication. Oxford. UK.

4. Fahmi, M. Adrim, \& Dharmadi. 2008. Kontribusi ikan pari (Elasmobranchii) pada perikanan cantrang di Laut Jawa. Pusat Penelitian Oseanologi, Lembaga Pengetahuan Indonesia. Jakarta, pp. 295-301.

5. Fauzi, A. 2005. Kebijakan perikanan dan kelautan, isu, sintesis, dan gagasan.Jakarta: PT Gramedia Pustaka Utama.

6. Hart, J.L.1973. Pacific Fishes of Canada. Fisheries Research Board of Canada. Buletin, $180,56-64$

7. Manik, N. 2003. Beberapa catatan mengenai ikan pari. Oseana, 28(4). hlm.17-23

8. Pelabuhan Perikanan Nusantara Brondong. 2015. Statistik perikanan tangkap PPN Brondong 2015. Pelabuhan Perikanan Nusantara Brondong. Lamongan.

9. Subani, W. \& H.R. Barus. 1989. Alat Penangkapan Ikan dan Udang Laut di Indonesia. Jurnal Penelitian Perikanan Laut, 50. Jakarta: BPPL-BPPP. Departemen Pertanian.

10. Utami, M.N.S., Redjeki, S., Jaya, N.T.S.P. 2014. Studi Biologi Ikan Pari (Dasyatis sp) di TPI Tasik Agung Rembang. Jurnal Marine Research Volume 2 No. 3. 